\title{
Student Experiences in an Online First-Year Seminar Paired with Remedial Mathematics
}

\author{
Max L. Walling, Sam Houston State University \\ Dana Van De Walker, Sam Houston State University \\ Kathleen Gilbert, Sam Houston State University \\ Matthew Olmstead, Sam Houston State University \\ Forrest C. Lane, Sam Houston State University
}

Educational research has explored the influence of first-year seminars, online course delivery, and developmental coursework on first-year student success, yet there is limited research on how these educational components intersect. A collective case study approach was used to explore the experiences of students enrolled in an online first-year seminar that was paired with a developmental mathematics course. Students reported different motivating factors and expectations for enrolling in the course, yet all expressed a desire to improve their academic performance and confidence. These results help to inform how delivery of an online FYS can support the goals of students and institutions.

Nearly $40 \%$ of college students are reported to take at least one remedial course in college (Ganga, Mazzariello, \& Egecombe, 2018). This lack of preparedness often costs students valuable time and money, also placing an additional burden on institutions (U.S. Department of Education, 2017). Moreover, students who are placed into remedial courses are less likely to complete their degree programs compared to those students who are able to enroll directly in college-level courses (Bailey et al., 2016; Levin \& Calcagno, 2008). This has resulted in a need for programs and services that support the degree completion of underprepared students. 
One approach for increasing student success in remedial courses is to link them with first-year seminars (Goodman \& Pascarella, 2006). Firstyear seminars support academic skill development and are associated with positive outcomes such as increased retention and persistence. Although most institutions offer first-year seminars, they are not always targeted to students enrolled in remedial courses. Data from the 20122013 National Survey of First-Year Seminars indicated that only 20.7\% of 2-year colleges and 3.0\% of 4-year colleges required students placed into remedial courses to participate in first-year seminars (Young \& Hopp, 2014). This is further complicated by the growth in online courses and instructional practices for students. As many as $37 \%$ of college students take at least one online course in any given semester (Allen, Seaman, Poulin, \& Straut, 2016). In the context of remedial courses, computerassisted delivery methods (e.g., Emporium model) are increasingly used as an instructional approach. More integrated strategies are needed to support the learning needs of underprepared students. To date, few studies have explored the experiences of online first-year seminars for students placed into remedial courses. This qualitative case study explored the expectations and experiences of students placed into a first-year seminar paired with a remedial mathematics course.

\section{Review of Literature}

Many students admitted into colleges and universities are deficient in the literary and mathematical skills required for placement into collegelevel course work. Yet, developmental or remedial courses help to ensure students have equal access to post-secondary educational opportunities. Bahr (2012) suggested that "many of the ascribed characteristics that are correlated with attainment (e.g., race/ethnicity, socioeconomic status) also are correlated with need for remedial assistance at college entry" (p. 662). As a result, remedial courses tend to serve our most at-risk student populations. It is necessary to identify how developmental education can help meet the myriad of needs for a diverse learning student population. For underprepared students to be successful in remedial coursework, 
colleges should focus on literary skill development, integration of a variety of educational teaching methods, and early introduction into mainstream curriculum (Brothen \& Wambach, 2012).

A critical component of fostering academic skill development is to support underprepared students for the diversity of instructional technologies in college (e.g., online instruction). A challenge is that some faculty may be less familiar with certain technologies or are reluctant to utilize content-based software programs (Zientek, Skidmore, Saxon, \& Edmonson, 2015). Many of today's generation of college students are digital natives, but these competencies must often be learned by faculty and administrators (Keup, 2018). Faculty also reported a wide variety of barriers to using technology (Martirosyan, Kennon, Saxon, Edmonson, \& Skidmore, 2017). Some of these barriers included the lack of institutional technology support, the perceived time commitment for additional use of technology in the classroom, and limited technology expertise (Martirosyan et al., 2017).

Faculty familiarity with technology may explain the mixed results in the literature related to the effectiveness of certain online courses. Zavarella and Ignash (2009) observed that students enrolled in a faceto-face remedial course had a completion rate of $80 \%$, whereas those enrolled in a hybrid course or an online course had a completion rate of 58\% and 61\%, respectively. In contrast, Ashby, Sadera, and McNary (2011) conducted a similar study and noted that students enrolled in online remedial courses had not only a higher completion rate but also a higher assignment completion rate than did students enrolled in traditional face-to-face developmental courses. Improvement in online instruction techniques and evolution of online instruction technologies may help serve as an explanation of these mixed results.

Understanding student expectations of online education is vital because learning styles have evolved with the rapid integration of technology in higher education, particularly as institutions have increased their offering of online coursework to meet a growing number of students enrolling in online and hybrid courses (Allen et al., 2016). A study conducted by Nadelson et al. (2013) examined first-year student 
expectations and revealed a positive correlation between student expectation and experience when academic support and curriculum aligned with the students' intrinsic motivators (i.e., career, academic, and learning goals). Stewart, Bachman, and Johnson (2010) identified commonalities that contributed to student motivation and interest to enroll in online coursework, including scheduling and time constraints, particularly for students who worked between 21-40 hours a week, adult learners, and students with families. This study further concluded that student motivation and interest to enroll in online coursework increased with each online course the students completed, which could account for the climbing enrollment in online courses by both traditional and nontraditional students.

As students begin to take more courses online, institutions will need to better support the skill development of students in this context. Kuh (2008) identified 10 high impact educational practices (HIPs) of undergraduate education which have become widely used strategies for improving student retention and degree completion rates of college students. A challenge is that the literature on the use of HIPs has focused more on "programs that take place in face-to-face environments on residential campuses" (Linder \& Hayes, 2018, p. 1). Explorations about the effectiveness of HIPs in an online context remains limited, despite the growth in online courses nationally.

First-year seminars are one of the 10 HIPs that support learning and are associated with increased persistence, retention, and graduation rates for students (Rutschow \& Schneider, 2011). Some institutions have found success by combining first-year seminars with remedial courses. For example, students entering on probationary status and who enrolled in a first-year seminar passed their courses and held a higher GPA at the end of the term than students who had not enrolled (Barnes, 2012). Additionally, students dually enrolled in developmental courses and first-year seminars were also reported to persist from the fall to the spring semester at higher rates. A reason for the success of these students was the ability of first-year seminars to support skill development. Barbatis (2010) conducted a study of a first-year learning community for underprepared 
students and identified several themes related to retention. Students who were persisting commonly mentioned the importance of a sense of responsibility, goal orientation, and determination. This finding is consistent with literature about the importance of psychosocial factors in the academic success of college students (Robbins et al., 2004).

Despite our knowledge about the effectiveness of first-year seminars for students placed into remedial courses, less is known about the experiences of these students in an online context. In a study of firstyear students generally, Foote and Mixon-Brookshire (2014) found that faculty delivering online first-year seminar courses struggled to create an engaging learning environment. In particular, they discovered that although students valued regular email communication with their professors, they disliked online group discussion boards and had a more difficult time making social connections. A limitation of this study is that it did not look specifically at students dually enrolled in remedial courses. Given the high percentage of students placed into remedial courses and the struggle of these students to complete remedial course sequences (Bailey, Jeong, \& Cho, 2010), it is important to examine targeted strategies for this population, especially as it relates to academic support (i.e., tutoring, supplemental instruction, bridge programs, etc.) (Martirosyan, et al., 2017). There is also a need to explore the experiences of students in the context of mathematics courses. Barbatis (2010) suggested that "Developmental education can greatly benefit from continued studies that listen directly to students' voices and perceptions of their own college experiences," particularly in the context of mathematics (p. 23). This study bridges that gap in the literature by exploring the experiences of students in an online first-year seminar paired with developmental mathematics.

\section{Theoretical Framework}

Tinto's (1987) theory of student departure served as the major theoretical foundation for this study. The major tenets of Tinto's (1987) theory include pre-entry attributes (i.e., family background, skills, and prior schooling), students' goals (i.e., motivation and sense of purpose), institutional experiences (i.e., formal and informal interactions), and 
academic and social integration (i.e., involvement in the social and academic environments). Accordingly, this model suggests that student departure from college is a function of their commitment as well as their academic and social integration into the college or university environment. A primary function of first-year seminars is to help students adjust to their new environment and overcome academic and social hurdles, with a goal of preventing student attrition (Keup \& Petschauer, 2011). This theoretical framework is even more poignant when discussing students who are dually enrolled in a first-year seminar and developmental coursework. Two interactional roots of institutional departure related to first-year students are adjustment and isolation (Tinto, 1987). Both of these roots of institutional departure are key focal points of first-year seminar curriculum (Keup \& Petschauer, 2011). Many first-year seminars strive to include curriculum on adjusting to a new academic environment (e.g., visiting the library or the tutoring center) and on creating meaningful relationships with others (e.g., visiting a professor's office hours or taking part in class group work).

\section{Purpose of Study and Educational Significance}

To date, few studies have explored how an online first-year seminar can support students enrolled in developmental courses. To better understand that relationship, we explored the expectations and perceptions of students enrolled in an online first-year seminar that was paired with a developmental mathematics course. This may help institutions better understand the efficacy of such approaches to supporting student success.

\section{Research Questions}

In order to establish a guide for our study, we identified the following three research questions: (a) What were university students' expectations in regard to taking an online first-year seminar tied to their developmental mathematics course?; (b) What were university students' perceived outcomes of their participation in a first-year seminar tied to their developmental mathematics course?; and (c) In what ways were university 
students' educational needs met or unmet by taking an online first-year seminar tied to their developmental mathematics course?

\section{Method}

We employed a collective case study design to explore the expectations and perceptions of students enrolled in an online firstyear seminar. We also used Berger and Luckmann's (1966) social constructionism as a research paradigm to understand how the individual students within the program constructed and created cultural significance with other group members and the course itself, including assigning meaning through their experiences. Social constructionism employs the use of observation as it focuses on participants' experiences and societal interactions to help determine a shared understanding (Berger \& Luckmann, 1966). An advantage of this approach is the close collaboration between the researcher and the participant, providing the support to the participant to express his or her experiences (Berger \& Luckmann, 1966).

\section{Participants and Setting}

CThis study was conducted at a regional university in the south with a student population of over 20,000 as of fall 2018. Approximately 18,000 were undergraduate students and 2,800 were first-time enrolled freshman. Approximately $10.0 \%$ of students at the institution were enrolled in fully online programs with another $39.0 \%$ of students reported to have taken one or more courses online at the institution (U.S. News \& World Report, 2018). The university reported that $44.5 \%$ of the student population were students of color $(21.7 \%$ Hispanic/Latino, 17.4\% Black, 3.0\% Bi-racial, 1.8\% Asian, and 0.6\% Native America/Pacific Islander) and that approximately $67.9 \%$ of undergraduate students received some type of financial aid (Forbes, 2018).

The focus of this study was students enrolled in an online undergraduate first-year seminar. All students enrolled in this online seminar course were required to dually enroll in a developmental mathematics course as a prerequisite. Based on this criteria, 398 students 
were eligible to participate and 10 chose to enroll in the course. All students enrolled in the online course had access to the on-campus university resources and could co-enroll in other online and face-to-face courses at the institution. One of the students in the online first-year seminar was reported to be full-time enrolled in online courses only. The online first-year seminar course was comprised of half men and half women, most of whom were first-time, full-time enrolled freshman. Three of the students in this seminar chose to participate in this research study. Two students were classified as sophomores and one was classified as a junior based on credit hours at the institution. All three participants self-identified as being non-traditional students, with one identifying as first generation, another reporting they were homeschooled, and the third having a daughter who was concurrently enrolled in college. The non-traditional makeup of these participants represented the broader diversity of students served by developmental education. Four of the students enrolled in the online first-year seminar were also enrolled in a developmental reading and writing course in addition to a developmental mathematics course.

We invited students to participate in the study through email communication and offered a small financial incentive (i.e., gift card) for their participation. Three students responded to the invitation and were given the following pseudonyms to protect their identities and to ensure confidentiality: (a) Elena, (b) Isaac, and (c) Tracy. Tracy was a single parent and full-time employee working night shifts while completing her coursework. Her interview was conducted at 7:00 am to accommodate her work and family schedule via video chat application. Isaac came from a non-traditional background, meaning he was homeschooled in high school. He showed up 30 minutes late to his interview, which he contributed partially due to his need to be organized and efficient in being self-disciplined in his study and organization of time. Elena identified as a first-generation college student, a daughter from an immigrant family, and a non-native English speaker. As a first-generation student, she admitted that she struggled with organization and scheduling, and missed her originally scheduled interview. 


\section{Data Collection}

Elena and Isaac were interviewed face-to-face while Tracy was interviewed through a video chat application. We used a semi-structured (Janesick, 2010) interview protocol and encouraged collaborative dialogue to gain a better understanding of the students' experiences in the seminar course. In addition to the main interview questions, we asked several follow-up questions that helped us gain clarification of interview responses and allowed for further probing for richer detail.

\section{Verification Procedures}

Verification procedures were used to ensure true representation of the research process and demonstrate the rigor of the study (Given, 2008). Lincoln and Guba (1985) offered four criteria for ensuring trustworthiness of findings: (a) credibility, (b) transferability, (c) dependability, and (d) conformability. Additionally, member-checking was utilized for safeguarding the credibility of findings (Manning, 1997). We initiated the application of member-checking via email approximately 2 weeks after the conclusion of the interviews with Elena, Isaac, and Tracy, and none requested changes to their transcript. Additionally, a single debriefing interview of each researcher (Onwuegbuzie, Leech, \& Collins, 2008) took place 2 weeks following the interviews of Elena, Isaac, and Tracy. These debriefing interviews allowed us to reflect upon our perceptions and observations of our respective interviews and how our perceptions might have impacted the participants' responses (Onwuegbuzie et al., 2008). We selected debriefing questions from a comprehensive list suggested by Onwuegbuzie et al. (2008) in an effort to minimize researcher bias through reflexivity.

\section{Analysis}

We used a constant comparison analysis to code data into themes to create a theory related to student experiences in an online first-year seminar (Glaser, 1965). Strauss and Corbin (1990) described three steps of coding the data used in a constant comparison analysis: (a) open coding, (i.e., examination and categorizing of the data); (b) axial coding, 
(i.e., a reexamination and recording of the previously created categories into themes); and (c) selective coding, (i.e., an examination and validation of the categories and the relationship among the themes to create a theory). As noted by Constas (1992), the categories used for a constant comparison analysis should include three components of categorization. Each of these categories is associated with a central question of categorization: (a) origination; (b) verification; and (c) nomination (Constas, 1992). Furthermore, Constas (1992) explained that the categories could stem from interviews with the research participant, the programmatic language, the investigation, the literature review, or the interpretations of the data. The constant comparison categories of this study stemmed from our interpretations of the data and conversations with Elena, Isaac, and Tracy and were completed using QDA Miner Version 5.0.23 (Provalis Research, 2016).

\section{Limitations}

One significant threat to the internal credibility of this study concerned observational bias. Onwuegbuzie and Leech (2007) described this threat to legitimation as occurring when the researchers collect an inadequate quantity of data from participants, providing an incomplete analysis. In an effort to minimize observational bias, interview questions were co-constructed by all researchers involved in the study. Additionally, we developed the questions to be open-ended in order to gain as much insight from the participants as possible. Furthermore, we asked followup questions to ensure understanding and clarity of the participants' responses. Finally, the threat of descriptive validity (i.e., the accuracy and adequacy of participants' responses) was recognized as a threat to internal credibility.

The greatest threat to the external credibility of the findings within this study concerned interpretive validity. Maxwell (1992) described interpretive validity as how precisely the researcher captures the perspective of the participant, such as misinterpreting the interviewed participant's views and/or experiences due to their own experiences. In addition, because we assigned meaning to the findings, and acknowledged the threat of interpretive validity of the data, we also considered how 
the data could sway the research community (i.e., catalytic validity). To enhance interpretive validity of the research study, we included Elena's and Isaac's exact words to enhance the understanding of their experiences, as discussed.

\section{Results}

A constant comparison analysis of Elena, Isaac, and Tracy's interview transcripts, totaling 5,534 words, revealed 23 codes. We categorized these codes to reveal five main categories pertaining to: (a) academic resources, (b) challenges, (c) skill development, (d) community building, and (e) support. We continually reviewed and analyzed all three transcripts to identify concepts of analysis in the grounded theory method (Strauss \& Corbin, 1990), and compared for similarities and differences. Through constant comparison of the data and reorganization of the codes, similar concepts emerged leading to the identification of mutually exclusive categories. Once we analyzed the five categories, we identified three main themes: (a) university integration and support, (b) personal motivation and challenges, and (c) academic confidence and competency (Table 1). 


\section{Table 1}

Constant Comparison Analysis Categories and Codes

\begin{tabular}{ll}
\hline Category & Codes \\
\hline resources & class structure \\
resources & course \\
resources & career center \\
resources & online library \\
resources & assignments \\
challenges & writing \\
challenges & homework \\
challenges & group feedback \\
challenges & procrastination \\
challenges & balance \\
challenges & distance \\
skill development & strategy development \\
skill development & time management \\
skill development & communication \\
skill development & career planning \\
skill development & attitude \\
community building & group assignments \\
community building & group communication \\
community building & social interaction \\
support & classmates \\
support & discussion boards \\
support & professor \\
support & positive encouragement \\
\hline
\end{tabular}

Note. Codes within the table were produced within QDA Miner Version 5.0.23 (Provalis Research, 2016), and categories were established a posteriori and composed and designated during the investigative analysis of the transcript by the researchers. 
University integration and support. Elena, Isaac, and Tracy each spoke to how the enrollment in the online seminar would provide opportunities for them to integrate at their university. However, motivations for course enrollment were notably distinguished for each participant and included personal identity factors, understanding of a new community, and developing awareness of university resources. Further, Elena, Isaac, and Tracy all expressed identities of non-traditional college students (i.e., first-generation, homeschooled, adult learner) during their discussion of university integration: Isaac disclosed that he was homeschooled before starting college, Elena revealed that she was a first-generation college student who spoke Spanish as her primary language, and Tracy shared that she was a fully online student who worked as a full-time employee and had children currently enrolled in college. Isaac explained his motivation for enrolling in the online first-year seminar with the following statement:

I enrolled because I felt that it could help me. Being a freshmen [that] never went to public or private school because I was homeschooled kind of felt like a setback. ... It's making me fit into college life because I never had been in a community setting [before]. But now I'm here, and it's helping me to learn about the social side of college. Getting to work with other kids and some of those kids having the same [interests] as me is really helpful.

While Isaac focused more on the social component of university integration, Elena and Tracy concentrated heavily on the resources they each had hoped to gain from the online freshman success seminar. Elena stated:

My expectation [of the course] was [receiving] university resources. Learning what are the expectations of college? What strategies do you need for college? What attitude [should one] obtain in college? All of those things. . . because [the resources] relate to what I'm doing in other classes. . . resources like [the university's scholarly article database]... and tutoring. . . have helped the most.

Tracy echoed similar sentiments to Elena in the following statement:

I did expect to get [from the course] different types of resources 
changing up how I did stuff... Like studying [and] trying to break it up [monotony] so you know you [don't get bored], and you don't want to do it anymore [persist through the degree]. So it has helped me look at my goals differently with the job and look at different ways that I can use my degree as well.

Additionally, in the interview, Elena, Isaac, and Tracy each spoke to the support they received from the professor or classmates of the online first-year seminar. Elena and Tracy each noted how the professor conveyed genuine interest in them, communicated course requirements and expectations effectively as well as responded with timeliness to any concerns or questions, and challenged students with unique assignments that required critical thinking. Tracy described in length how the structure of the course and the communication by the professor had been beneficial to her regarding support:

One thing that I will say I do like the fact that the professor is so hands on.... he's constantly emailing "Hey guys, do you need help?" He's encouraging and reaching out to me to call or email if we need help. So, that part has really been a big part [of feeling supported]. [The semester has been] really different because I only have one other one or two of the classes that the professors actually do that [communicate effectively]... he's more hands-on and that to me it makes the it makes the students feel a lot more comfortable to ask [questions about course assignments or in general].

However, Isaac focused on the support he received from his classmates, highlighted in the following excerpt:

What I learned from it is just how to get together as a group and just do these problems to where it's making me fit into the college life. Because I had never been in a community setting you know... .I feel like whenever they put up discussions, I can really find out about a person and their viewpoints and they sometimes have the same viewpoint as I do and I can relate to that somebody I know that I could go to help me with my situation.

Personal motivation and challenges. The second theme derived from the interviews with Elena, Isaac, and Tracy was that of personal motivation 
and challenges. Collectively, each discussed how enrolling in an online first-year seminar would provide opportunities for the development of skills that are essential to college success. For each of the participants, the discussion related to skill development focused on recognizing personal deficits that they hoped to address and rectify through the online firstyear seminar, most notably deficiencies related to identifying weakness in a particular subject matter, procrastination, time management, and communication among workgroup members. We interpreted their desire for skill development as a motivator to enroll in the online firstyear seminar. In the interview with Tracy, she shared her motivation for enrolling in the online success seminar in the following account:

It said it would help me with the math because I know that my weakness. And so [the course] was supposed to [provide a] strategy on how to gain new concepts of studying and learning the different topics and how to study different [subjects]. So that was that's what peaked my interest.

Isaac referenced his background of being homeschooled as a motivation to connect to others in the following statement related to his motivation to enroll:

I was expecting just to get to learn about the social side of the college you know. Just get to work with other kids you know and some of those kids having the same [interests] as me you know. ... Now we're getting to the group projects too where we all have to work together communicate through email etc., you know and I just never had to communicate.

Finally, Elena spoke to her motivation to enroll in the course as being explicitly based on the professor teaching the course as exemplified in the following account:

I choose the online section because I was originally supposed to take [the first-year seminar] face-to-face with [a specific professor] ... .but yeah that's why I choose that section [online format]... . I liked the professor. I actually met him in person once at the teacher education center.... he's really helpful. He actually cares about students in this course. 
Later in the interview, Elena further described skills she was developing, as an additional motivator for her enrollment in the course was to handle student procrastination that the online first-year seminar "is teaching me to slow down.... it's taught me that [I] need to set a schedule for [my] study habits so that [I] have [time] and don't cram on it." Each of the participants presented a wide range of challenges as motivation in their decision when enrolling in the online success seminar.

Academic confidence and competency. Elena, Isaac, and Tracy each shared how the first-year seminar had helped them gain confidence in their ability to navigate the challenges of future coursework. The students' confidence and competency came from three primary components each shared they gained from the first-year seminar: (a) resources, (b) support, and (c) skill development. Elena spoke to feeling competent in her ability to now handle the rigor of the coursework in future courses due to having been enrolled in the online success seminar and the resources she received, as represented in the following account:

I would actually recommend some students take this course. Like for those who haven't signed up for the first year learning communities or in the math community. So I would recommend it. ... Because I know some students... . know they don't know how to have access to those sorts of resources that the course itself offers. You know I've actually had students like come up to me and say "hey, how do we do this?" And "how do I do that?" and it is things that the course has actually taught me. So that's why I would actually recommend it. So students that feel like they're struggling in college and they need to learn more.

Further, in the conversation, Elena attributed confidence in her ability to be successful in future courses because of enrolling in this course in the following excerpt:

Yeah I feel like I would [be successful]. Because I learned some things that I hadn't known before in this course, so it will benefit me like I guess students should take it. So it will benefit them in the future courses they will take.

Both Isaac and Tracy discussed how the curriculum provided multiple 
resources that allowed them to take an in-depth look at their current skill set and areas they could improve. Tracy spoke directly to how this has enabled her to look closely at her weaknesses and build upon them, increasing her confidence in coursework in the following paragraph:

With this class because you have to speak up... you have to actually talk to someone [and] go to your [career advisor] and do a career visit and get these different critiques. You actually have in front of you exactly what you need to take next semester and kind of go over you know the different the different classes and different areas [skills] that you need to improve in or whatever. So you got to find out a lot more about yourself than what I thought the class was it initially will be about you find out a lot more about yourself weaknesses your strengths then you learn [how to perform] the SWOT analysis. You end up learning how to I guess how to even though you have those weaknesses you learn from those weaknesses and how to make those in the strengths actually.

In conversation with Isaac, he detailed his perceptions and expectations of the course being mid-way into the semester stating, "I've gotten a lot out of this curriculum and it's helped with a lot of things. [My] Expectations are pretty high. So they haven't really changed."

\section{Discussion}

Building upon the findings of Foote and Mixon-Brookshire (2014), we sought to fill a gap in the literature by examining the experience of students enrolled in an online first-year seminar paired with developmental coursework. The major findings of the constant comparison analysis (Glaser \& Strauss, 1967) established three categories: university integration and support, personal motivation and challenges, and academic confidence and competency. The findings demonstrated that participants believed participation in an online first-year seminar would provide opportunities for the development of academic success skills (i.e., time management, teamwork, and effective communication) essential to be a successful student throughout their coursework. All participants reported that their primary educational needs were met as a result of 
enrolling in the online first-year seminar, and each specifically noted that the development of academic success skills were a foundational takeaway from the first-year seminar. Additionally, some students explicitly noted their experience in the first-year seminar led to an increase in their confidence to be successful in their current developmental mathematics course and in future courses, which is supported by Robbins's et al. (2004) meta-analysis revealing the importance of self-efficacy on student success.

The participants in this study all agreed that the online interaction with the course faculty member played a positive role in their perceptions of university integration and support. For one participant, Elena, interactions with the course instructor both in person and online were highly important to her experiences of university integration and support. For the other two participants, the impact of faculty interaction was briefly mentioned as having a positive or neutral influence. These findings contrasted with prior research on the perceptions of students in an online first-year seminar where lack of faculty interaction was seen as a barrier to success (Foote \& Mixon-Brookshire, 2014). Participant perceptions of faculty interaction in this study align more closely with the broader body of literature concerning the importance of faculty interaction as a critical component of student success (Boudreau \& Kromrey, 1994; Schlossberg, Lynch, \& Chickering, 1989; Shanley \& Witten, 1990), but it is important to note that research concerning online courses generally is mixed about the relative importance of student-instructor versus student-student interaction (Jaggars \& Xu, 2016).

Both Elena and Isaac discussed the importance of the seminar in providing opportunities for academic integration into the university. The need to integrate successfully into their university via online course delivery is aligned with other studies that report successful undergraduate student integration leads to persistence and degree completion (Goodman \& Pascarella, 2006; Tobolowsky, 2014). Tracy discussed her desire to succeed in her developmental math class as a strong motivating factor for enrolling in the first-year seminar. Prior research also has addressed the value of paired first-year seminars and developmental courses with student persistence (Barnes, 2012; Foote \& Mixon-Brookshire, 2014). The 
approach of using an online first-year seminar did not seem to discourage or create additional perceived barriers for these students.

For these participants, the need for academic integration and support were highly varied. Elena was motivated to enroll for the purpose of gaining new resources that would assist her through her college career. In contrast, Isaac enrolled for the community-setting aspect. Tracy, meanwhile, enrolled in the first-year seminar to help herself gain confidence in her math proficiency. In all instances, the motivations of the students seemed to be related to their transition into college. This is consistent with Garza and Bowden's (2014) assertion that first-year programs "were designed to ease the transition into higher education" (p. 409). Additionally, Garza and Bowden's (2014) research findings indicated that when first-time college students were required to take a developmental course, retention rates increased, leading to student success. However, the importance of social versus academic integration likely depends on the student and this should be considered when developing first-year seminar curriculum for online students.

\section{Limitations and Recommendations}

Because participation in this study required dual enrollment in developmental mathematics and an online first-year seminar, the pool of participants was limited. Despite offering a substantial incentive for participation, we experienced difficulty recruiting participants. This may reflect continued concerns about online course quality, despite a growing demand for them. Findings in Krug, Dickson, Lessiter, and Vassar (2016) suggested students were more apprehensive about taking upper-level courses online, but indicated that lower-level online courses in general education were acceptable. A larger sample of students would provide a more diverse insight related to student expectations and perspectives. Future researchers may benefit from leveraging course-based assessments and reflections related to student experiences, perspectives, and outcomes formally into the course so that more data are available, even within courses that have low enrollments.

Given the importance of effective communication on student 
learning (Balkin, Buckner, Swartz, \& Rao, 2005; Soffer, Kahan, \& Livne, 2017; Tee \& Karney, 2010), online instructors may want to investigate how communicative strategies and methods with students, both within the institutional learning management system and outside of it, can be leveraged to improve student communication and engagement. Students perceived value in the online first-year seminar (e.g., university integration, social support, skill and confidence development) but also indicated challenges in communicating with peers. There is need to explore which specific online activities lead to the most meaningful interaction, engagement, and educational development of these students. Conducting short live sessions and assigning roles to students, such as learner-facilitated discussions, can help to build engagement in online courses (Banna, Lin, Stewart, \& Fialkowski, 2015). Instructors may also want to leverage social media (e.g., Facebook groups, GroupMe, Twitter) to encourage more peer-to-peer social interaction.

The results from this study were encouraging, but they did not address the issue that some faculty may not feel prepared to use technology or teach in an online environment. This was a concern raised by Zientek et al. (2015) and Martirosyan et al. (2017). It would seem reasonable that without more faculty training, the results from this study will only add to the mixed findings of online courses. One way to support technology concerns of faculty is to develop an online training course for faculty who teach online. An orientation of the institution's learning management system, as well as activities that promote an awareness of online teaching tools, can develop better online teaching practices (Alexiou-Ray \& Bentley, 2015).

\section{Conclusion}

Prior research has suggested that placement in developmental courses is related to retention rates and degree completion (Bailey et al., 2016; Levin \& Calcagno, 2008) and that student participation in a firstyear seminar may positively affect this relationship (Barnes, 2012; Foote $\&$ Mixon-Brookshire, 2014). The demand for online courses and use of 
computer-centered instructional delivery for developmental education has increased over the years. However, there is a lack of information about the intersection of these educational experiences. This collective case study examined the experiences of students enrolled in an online first-year seminar and found that the expectations and perceived value of the course were the ability to support the transition into college. This suggests an online format can be an effective option for students placed into developmental education.

\section{References}

Alexiou-Ray, J., \& Bentley, C. C. (2015). Faculty professional development for quality online teaching. Online Journal of Distance Learning Administration, 18(4), 1-6.

Allen, L. E., Seaman, J., Poulin, R., \& Straut, T. T. (2016). Online report card: Tracking online education in the United States. Retrieved from Babson Survey Research Group website: http://onlinelearningsurvey.com/ reports/onlinereportcard.pdf

Ashby, J., Sadera, W. A., \& McNary, S. W. (2011). Comparing student success between developmental math courses offered online, blended, and face-to-face. Journal of Interactive Online Learning, 10, 128-140.

Bahr, P. R. (2012). Deconstructing remediation in community colleges: Exploring associations between course-taking patterns, course outcomes, and attrition from the remedial math and remedial writing sequences. Research in Higher Education, 53, 661-693. doi:10.1007/ s11162-011-9243-2

Bailey, T., Brashford, J., Boatman, A., Squires, J., Weiss, M., Doyle, W., ... Young, S. H. (2016). Strategies for postsecondary students in developmental education - A practice guide for college and university administrators, advisors, and faculty. Washington, DC: Institute for Education Sciences, What Works Clearinghouse.

Bailey, T., Jeong, D. W., \& Cho, S. W. (2010). Referral, enrollment, and completion in developmental education sequences in community colleges. Economics of Education Review, 29(2), 255-270. doi:10.1016/j.econedurev.2009.09.002 
Balkin, R. S., Buckner, D., Swartz, J., \& Rao, S. (2005). Issues in classroom management in an interactive distance education course. International Journal of Instructional Media, 32(4), p363-372.

Banna, J., Lin, M. F. G., Stewart, M., \& Fialkowski, M. K. (2015). Interaction matters: Strategies to promote engaged learning in an online introductory nutrition course. Journal of Online Learning and Teaching, 11(2), 249. doi: 10.1037/e527582014-009

Barbatis, P. (2010). Underprepared, Ethnically Diverse Community College Students: Factors Contributing to Persistence. Journal of Developmental Education, 33(3), 16-26.

Barnes, J. (2012). The first-year experience impact on student success in developmental education. The Journal of Applied Research in the Community College, 20(1), 27-35.

Berger, P., \& Luckmann, T. (1966). The social construction of reality: A treatise in the sociology of knowledge. Garden City, NY: Anchor Books.

Boudreau, C. A., \& Kromrey, J. D. (1994). A longitudinal study of the retention and academic performance of participants in freshmen orientation course. Journal of College Student Development, 35(11), 444-449.

Brothen, T., \& Wambach, C. A. (2012). Refocusing developmental education. Journal of Developmental Education, 36(2), 34-39.

Constas, M. A. (1992). Qualitative analysis as a public event: The documentation of category development procedures. American Education Research Journal, 29, 253-266. doi:10.3102/00028312029002253

Foote, S. M., \& Mixon-Brookshire, D. (2014). Enhancing learning with technology: Applying the findings from a study of students in online, blended, and face-to-face first-year seminar classes. Teaching and Learning, 6(2), 35-41.

Forbes. (2018). America's top colleges 2018. Retrieved from https://www. forbes.com/top-colleges/\#7cfe30411987

Ganga, E., Mazzariello, A., \& Egecombe, N. (2018). Developmental education: An introduction for policy makers. Denver, CO: Education Commission of the States. 
Garza, E., \& Bowden, R. (2014). The impact of first year development course on student success in a community college: An empirical investigation. American Journal of Education Research, 2(6), 402-419. doi:10.12691/education-2-6-13

Given, L. M. (2008). The Sage encyclopedia of qualitative research methods. Los Angeles, CA: Sage. doi:10.4135/9781412963909

Glaser, B. G. (1965). The constant comparative method of qualitative analysis. Social Problems, 12, 436-445. doi:10.1525/ sp.1965.12.4.03a00070

Glaser, B. G., \& Strauss, A. L. (1967). The discovery of grounded theory: Strategies for qualitative research. New York, NY: Aldine De Gruyter.

Goodman, K., \& Pascarella, E. T. (2006). First-year seminars increase persistence and retention: Evidence from how college affects students. Peer Review: Emerging Trends and Key Debates in Undergraduate Education, 8(3), 26-28.

Jaggars, S. S., \& Xu, D. (2016). How do online course design features influence student performance?. Computers \& Education, 95, 270-284. doi:10.1016/j.compedu.2016.01.014

Janesick, V. J. (2010). Stretching exercises for qualitative researchers (3rd ed.). Thousand Oaks, CA: Sage

Keup, J. R. (2018). First-Year Seminars. In K. E. Linder \& C M. Hayes (Eds.), High impact practices in online education: Research and best practices (pp. 11-25). Sterling, VA: Stylus Publications.

Keup, J. R., \& Petschauer, J. W. (2011). The first-year seminar: Designing, implementing, and assessing courses to support student learning and success: Vol 1. Designing and administering the course. Columbia, SC: University of South Carolina, National Resource Center for The FirstYear Experience and Students in Transition.

Krug, K. S., Dickson, K. W., Lessiter, J. A., \& Vassar, J. S. (2016). Student preference rates for predominately online, compressed, or traditionally taught university courses. Innovative Higher Education, 41(3), 255-267. doi:10.1007/s10755-015-9349-0 
Kuh, G. D. (2008). High-impact educational practices: What they are, who has access to them, and why they matter. Washington, DC: Association of American Colleges and Universities.

Levin, H., \& Calcagno, J. (2008). Remediation in the community college. Community College Review. 35, 181-207. doi:10.1177/0091552107310118

Lincoln, Y. S., \& Guba, E. G. (1985). Naturalistic inquiry. Beverly Hills, CA: Sage.

Linder, K. E., \& Hayes, C. M. (2018). High impact practices in online education: Research and best practices (pp. 11-25). Sterling, VA: Stylus Publications.

Manning, K. (1997). Authenticity in constructivist inquiry: Methodological considerations without prescription. Qualitative Inquiry, 3, 93-115. doi:10.1177/107780049700300105

Martirosyan, N. M., Kennon, J. L., Saxon, D. P., Edmonson, S. L., \& Skidmore, S. T. (2017). Instructional technology practices in developmental education. Journal of College Reading and Learning, 47(1), 3-25. doi:1 $0.1080 / 10790195.2016 .1218806$

Maxwell, J. A. (1992). Understanding and validity in qualitative research. Harvard Educational Review, 62, 279-301. doi:10.17763/ haer.62.3.8323320856251826

Nadelson, L. S., Semmelroth, C., Martinez, G., Featherstone, F., Casey, A., \& Sell, A. (2013). Why did they come here? - The influences and expectations of first-year students' college experience. Higher Education Studies, 3(1), 50-62. doi:10.5539/hes.v3n1p50

Onwuegbuzie, A. J., \& Leech, N. L. (2007). Validity and qualitative research: An oxymoron? Quality \& Quantity: International Journal of Methodology, 41, 233-249. doi:10.1007/s11135-006-9000-3

Onwuegbuzie, A. J., Leech, N. L., \& Collins, M. T. (2008). Interviewing the interpretive researcher: A method for addressing the crises of representation, legitimation, and praxis. International Journal of Qualitative Methods, 7(4), 1-17. doi:10.1177/160940690800700401 
Provalis Research. (2016). QDA Miner (Version 5.0.23) [Computer software]. Montreal, Quebec, Canada: Author.

Robbins, S. B., Lauver, K., Le, H., Davis, D., Langley, R., \& Carlstrom, A. (2004). Do Psychosocial and Study Skill Factors Predict College Outcomes? A Meta-Analysis. Psychological Bulletin, 130(2), 261-288. doi:10.1037/0033-2909.130.2.261

Rutschow, E. Z., \& Schneider, E. (2011). Unlocking the gate: What we know about improving developmental education. New York, NY: MDRC.

Schlossberg, N. K., Lynch, A. Q., \& Chickering, A. W. (1989). Improving higher education environments for adults: Response programs and services from entry to departure. San Francisco, CA: Jossey-Bass.

Shanley, M. G., \& Witten, C. H. (1990). University 101 freshman seminar course: A longitudinal study of persistence, retention, and graduation rates. NASPA Journal, 27, 344-352.

Soffer, T., Kahan, T., \& Livne, E. (2017). E-assessment of online academic courses via students' activities and perceptions. Studies in Educational Evaluation, 54, 83-93. doi:10.1016/j.stueduc.2016.10.001

Stewart, C., Bachman, C., \& Johnson, R. (2010). Students' characteristics and motivation orientations for online and traditional degree programs. Journal of Online Learning and Teaching, 6(2).

Strauss, A., \& Corbin, J. (1990). Basics of qualitative research: Grounded theory procedures and techniques. Newbury Park, CA: Sage.

Tee, Y. T., \& Karney, D. (2010). Sharing and cultivating tacit knowledge in an online learning environment. International Journal of ComputerSupported Collaborative Learning, 5(4), 385-413. doi:10.1007/ s11412-010-9095-3

Tinto, V. (1987). Leaving college: Rethinking the causes and cures of student attrition. Chicago, IL: University of Chicago Press.

Tobolowsky, B. F. (2014). Paths to learning: Teaching for engagement in college. Columbia, SC: University of South Carolina.

U.S. Department of Education. (2017). Developmental education: Challenges and strategies for reform. Washington, D.C.: Author.

U.S. News \& World Report. (2018). The best colleges in America. Retrieved from https://www.usnews.com/best-colleges 
Young, D. G., \& Hopp, J. M. (2014). 2012-2013 National survey of first-year seminars: Exploring high-impact practices for the first college year (Research Report No. 4). Retrieved from the National Resource Center for The First-Year Experience and Students in Transition website: https://eric.ed.gov/?id=ED546831

Zavarella, C. A., \& Ignash, J. M. (2009). Instructional delivery in developmental mathematics: Impacts on retention. Journal of Developmental Education, 32(3), 1-13.

Zientek, L. R., Skidmore, S. T., Saxon, D. P., \& Edmonson, S. L. (2015). Technology priorities and preferences of developmental mathematics instructors. Community College Enterprise, 21(1), 27-46. 